\title{
Bankruptcy Exemptions, Credit History, and the Mortgage Market*
}

\author{
Souphala Chomsisengphet ${ }^{\dagger}$ and Ronel Elul ${ }^{\ddagger}$
}

September 2005

\footnotetext{
*We thank Mitchell Berlin, Bob Hunt, Richard Hynes, Kathleen Johnson, Pravin Krishna, Wenli Li, Karen Pence, Stephen L. Ross, Robert Sauer, Nicholas Souleles, Elizabeth Warren, David N. Weil, and Michelle White, and seminar participants at the OFHEO and the ASSA meetings, for many helpful suggestions. The views expressed in this paper are those of the authors and do not represent policies or positions of the Office of the Comptroller of the Currency or the U.S. Treasury, nor the Federal Reserve Bank of Philadelphia or the Federal Reserve System.

†Office of the Comptroller of the Currency (OCC), Washington, DC 20219. E-mail: souphala.chomsisengphet@occ.treas.gov

${ }^{\ddagger}$ Correspondent. Federal Reserve Bank of Philadelphia. E-mail: ronel.elul@phil.frb.org
} 


\begin{abstract}
We develop and test a model of mortgage underwriting, with particular reference to the role of generic credit bureau scores. In our model, scores are used in a standardized fashion, which reflects the prevalence of automated underwriting in industry practice. We show that our model has implications for the debate on the effect of personal bankruptcy exemptions on secured lending.

Recent literature has developed conflicting theories - and found conflicting results - seeking to explain how exemptions affect the mortgage market. By contrast, in our model exemptions are actually irrelevant to the mortgage underwriting decision. Instead, our model suggests that since exemptions are correlated with credit scores, some of the previous works findings of significant effects for exemptions may rather reflect a failure to fully control for creditworthiness. Merging data from a major credit bureau with the Home Mortgage Disclosure Act (HMDA) data set, we confirm these predictions of our model.
\end{abstract}

Keywords: Personal Bankruptcy, Mortgage Underwriting, Credit Scores

JEL Classification Numbers: G33, J41, K12, O57. 


\section{Introduction}

We develop and test a model of mortgage underwriting, highlighting an important feature of real-world underwriting: the use of generic credit bureau scores to infer an applicant's inherent quality. In our model mortgage lenders use credit scores in a standardized fashion, in that they apply a formula that does not take into account the special circumstances or geographic variation that might influence a particular score. We estimate our model and determine the impact that credit bureau scores have on the likelihood that a mortgage application will be approved.

Our theoretical predictions and empirical results also stand in contrast to recent work on the effect of bankruptcy exemptions on the availability of mortgage credit, in particular Berkowitz and Hynes [1] (henceforth BH) and Lin and White [2]. These papers develop conflicting models in which lenders condition underwriting decisions on exemptions; both papers also find support for their respective hypotheses in the HMDA data. While the previous literature models exemptions as directly affecting the mortgage market, we argue that they are actually irrelevant to the mortgage underwriting decision. We confirm this empirically and also show that some of the results of the previous literature may be explained by its not accounting for lenders' use of generic credit bureau scores.

By "generic credit bureau scores," we mean the scores which are akin to those commonly known as "FICO" scores, which are produced by each of the three major credit bureaus in conjuction with Fair Isaac (rather than custom-designed mortgage scores). That these scores play a critical role in the mortgage underwriting process is indisputable; for example, Temkin et al. [3] document that the use of these generic scores for underwriting purposes is widespread throughout the industry. And although lenders and underwriters assert that individuals are not rejected solely on the basis of poor scores, 
it is well known that a low score makes it almost impossible to obtain a prime mortgage. For example, a score below 620 is considered evidence by Freddie Mac that the "borrower's credit reputation [is] probably not acceptable"; Fannie Mae similarly advises that in such a case "there must be...extenuating circumstances" (see Temkin et al. [3]). The key factor driving the use of these scores - and, significantly, the standardized way in which they are used - is the increasing prevalence of automated underwriting. Automated underwriting itself has been strongly promoted by the GSEs (Fannie Mae and Freddie Mac), which pool mortgage loans for sale on the secondary market. ${ }^{1}$

We are, of course, not the first to note that borrower creditworthiness is an important factor in evaluating mortgage applications. Indeed, a desire to account for creditworthiness was one of the primary drivers behind the Boston Fed Study on mortgage discrimination (see Munnell et al. [5]). Two recent papers are also noteworthy for incorporating credit scores into an empirical examination of the mortgage market: Barakova et al. [6] and PenningtonCross and Nichols [7].

As we have already mentioned, an important aspect of our model is its implication for the debate on the role of bankruptcy exemptions in the mortgage market. The dramatic rise in personal bankruptcy filings over the past two decades has motivated research into the effect of bankruptcy laws on consumer credit markets. Particular attention has been devoted to the effect of the bankruptcy exemptions, which differ quite dramatically across states, and vocal lobbies have proposed reforming these laws and making them more uniform. These exemptions govern the assets which a filer can retain in bankruptcy; although rather detailed intricate in practice, ${ }^{2}$ they are often broken down into two broad categories: homestead exemptions (the

\footnotetext{
${ }^{1}$ For more on automated underwriting, see Straka [4].

${ }^{2}$ For example, Oklahoma law exempts 100 chickens, five dairy cows and calves under six months, ten hogs, two horses, 20 sheep and feed to last one year.
} 
amount of home equity which can be retained in a bankruptcy filing) and personal property exemptions (other assets). Several studies have found that higher exemptions make borrowers more likely to file for bankruptcy; see, for example, Fay, Hurst, and White $[8] .^{3}$ Furthermore, Gropp, Scholz, and White [10] have shown that more generous bankruptcy laws also make it more difficult for consumers to obtain credit.

This research has been undertaken in the context of unsecured credit, where bankruptcy exemptions can be reasonably hypothesized to have a significant effect on the default decision. By contrast, the effect of these exemptions on secured credit and, in particular, home mortgages (the most common such form of credit) is far less clear. The reason is that when lending is secured, the creditor has preferential access to the collateral and so exemptions would seem to play only a minor role at best. ${ }^{4}$

$\mathrm{BH}$ argue (as do we) that since mortgages are secured, their performance should be relatively unaffected by exemption levels. They further suggest that, in fact, there may be cases where higher exemptions can actually benefit the mortgage lender. In particular, they argue that higher homestead exemptions should reduce the incidence of mortgage default because they leave the borrower with more wealth after a bankruptcy filing, which may help him continue repaying his mortgage in the future. This is easiest to see in the case of a chapter 13 filing. Since the payments a debtor makes in chapter 13 must be at least as large as they would have been under chapter 7 , more generous exemptions make it easier to qualify for chapter $13 .{ }^{5}$ This facilitates the filer's retaining his home because under chapter 13, mortgage

\footnotetext{
${ }^{3}$ Note, however, that other work has not found a significant impact from exemptions, especially when using state-level (rather than individual) data; see Kowalewski [9].

${ }^{4}$ Furthermore, in the case of mortgages, deficiency judgments (in which amounts above the collateral value become unsecured debts subject to exemptions) are often prohibited.

${ }^{5} 11$ U.S.C. $\$ 1325(\mathrm{a})(4)$. The other condition is that "all of the debtor's projected disposable income...will be applied to make payments under the plan." (11 U.S.C. $\S 1325(\mathrm{~b})(1)(\mathrm{B}))$.
} 
payments can be deducted before calculating the "disposable income" (which must be turned over under the repayment plan). By contrast, for personal property exemptions, the sign is indeterminate because the positive "wealth effect" may be counterbalanced by a negative effect due to increased protection from deficiency judgments ${ }^{6}$ since lenders anticipate this protection, they may be less likely to lend. BH then examine the HMDA data and find support for the hypothesis that higher homestead exemptions lead to less restrictive terms on mortgage loans, i.e., a lower likelihood of being denied a mortgage. They also find that personal property exemptions do not have a statistically significant impact. ${ }^{7}$

By contrast, Lin and White [2] (henceforth LW) develop a model that leads them to the opposite conclusion, viz., that higher exemptions should result in a tightening of the terms of credit. They also begin with the presumption that exemptions should not affect the likelihood of mortgage default; although unlike BH, they do not have a "wealth effect." 8 The thrust of their argument is then to first observe, as we discussed above, that higher exemptions make personal bankruptcy more likely. They then suggest that when a foreclosure occurs in conjunction with a bankruptcy filing, it is more costly for the lender, since it is likely to involve additional delay (because the bankruptcy court must approve the foreclosure). ${ }^{9}$ Although the lender is

\footnotetext{
${ }^{6}$ Since the deficiency is unsecured, property exemptions apply.

${ }^{7}$ Some further supporting evidence for their hypothesis can also be found in Ambrose and Capone [11], who show that defaulters with low LTVs who also file for bankruptcy are $15 \%$ likelier to reinstate their mortgages than similar borrowers who do not file; this suggests that some borrowers are able to use the bankruptcy process to hold on to their homes.

${ }^{8}$ They assume that the homestead exemption is always higher than the amount due on the mortgage, so that the exemptions are orthogonal to the question of whether the borrower can continue paying the mortgage.

${ }^{9} \mathrm{By}$ contrast, $\mathrm{BH}$ argue that a bankruptcy may actually facilitate the foreclosure process. The arguments on both sides of this issue are somewhat difficult to resolve, but Springer and Waller [12] do present some empirical evidence that confirms that bankruptcy lengthens the foreclosure process; indeed, they find that it doubles it (to six months on av-
} 
entitled to collect additional interest to compensate him for this delay, ${ }^{10}$ the available assets may well not be sufficient to pay this interest, nor will these additional payments necessarily fully compensate the lender for all associated costs. As a result, they conclude that higher exemptions should lead to more rationing in the mortgage market, not because they affect the probability of default but rather because they increase the loss given default. They then test their hypothesis on the HMDA data (using a different time period than $\mathrm{BH}$ ) and find evidence to support their hypothesis.

We will show that our model may help explain some of these results, because it predicts that if an econometrician were to ignore borrower credit scores, he would find that exemptions appear to be significant(as LW do), but that when creditworthiness is fully accounted for, this effect disappears. As we explain below, the reason for this is that generic credit scores are themselves correlated with bankruptcy exemptions, since they are based (in part) on the performance of unsecured loans. We also document this correlation and empirically confirm the effect of omitting borrower creditworthiness. ${ }^{11}$

An examination of prevailing industry practice supports our contention that exemptions do not figure in the underwriting process. From the aforementioned Temkin study, as well as the documentation the GSEs themselves provide to support their automated underwriting systems, it is apparent that the criteria used by the GSEs include credit scores, income, down payment,

erage). The key issue (not addressed in the literature) is whether this has an economically significant impact. One way to explore would be to examine the "days" measure used by Pence [13], which is FNMA's state-by-state estimate of the number of days required for the foreclosure process. This does not seem to be correlated in any way with exemptions.

${ }^{10} 11$ U.S.C. 506 (b); we thank Rich Hynes for bringing this to our attention.

${ }^{11}$ We should mention that another possible explanation could be that mortgage lenders do care about exemptions, but that if political considerations militate against their use, they compensate by placing more weight on credit scores, since, as our results imply, the latter are correlated with exemptions (we thank Michelle White for pointing this out). A similar argument is also often made in the context of mortgage discrimination; see Ross and Yinger [14]. 
total liabilities, and the trend of property values in the neighborhood. In addition, special consideration is also given to individual derogatory events such as bankruptcies. However, one factor that is never mentioned as entering into their underwriting decision is bankruptcy law. Since Fannie Mae and Freddie Mac between them intermediate approximately $80 \%$ of all conforming mortgages, it is likely that this reflects prevailing industry practice. Although individual lenders are, of course, free to use other criteria (such as exemptions), forgoing access to automated systems is obviously costly. One can only speculate as to why these automated systems do not account for exemptions, but one reason may be that differentiating between states would obviously compromise the GSEs' attempts to form a broad political coalition (at a time when they are subject to increasing criticism); another reason may be that having geographically standardized criteria facilitates loan securitization. ${ }^{12}$

The plan of the paper is as follows. We first develop our theoretical model. This is a model of how information on past defaults can be used to infer borrower quality, i.e. a model of credit scoring. Given the standardized lender behavior we have documented above, we explore our model's implications for the relationship between exemptions and mortgage underwriting. We then estimate our model by imputing credit scores to the HMDA data from an independent sample of credit bureau records. We confirm that - when we control for borrower credit score - exemptions indeed have an insignificant effect on the likelihood that a mortgage application is approved. We conclude by showing that our model can explain some of the results of the previous literature, which find a significant effect from exemptions.

In our concluding remarks we also suggest that this phenomenon may be more general and that, as credit scores are more widely applied, one may

\footnotetext{
${ }^{12}$ The latter would also apply to non-conforming loans, which are also commonly securitized.
} 
expect to see more of these unintended effects.

\section{Model}

\section{A Introduction}

We begin by setting out a simple theoretical model of borrowing and repayment which motivates our investigation. This model will set out relationships between exemptions, credit scores and the mortgage market which we then explore in the empirical work below.

Consider a borrower with a fixed debt $D$, which is currently due; let $D \in[0,1]$. Also suppose that he has an asset $A$ whose value is stochastic and can take values in $[0,1]$ (for example, a house); to economize on notation we will assume for simplicity that neither future lenders nor ratings agencies can condition scores or lending decisions on past values of $A$, although this is not essential. Also suppose that the borrower has a private (unobserved) "disutility of default" $K$ - this could be due to personal or societal mores, or simply the cost of bankruptcy in terms of access to future credit; again, let $K \in[0,1]$. This approach — that of individual costs of default - was first used by Dubey, Geanakoplos, and Shubik [15, 16]; for an application to a mortgage market (with asymmetric information), see Brueckner [17]. For simplicity, we will assume that $K<D$, so that there is always the chance (however small) that the agent will default. Finally, suppose that the bankruptcy exemption in the borrower's state of residence is $E \in[0,1]$. For simplicity of exposition we combine the exemptions into a single number, although in our estimations (below) we distinguish between homestead and personal property exemptions.

We begin by assuming that the loan is unsecured. Then the amount of nonexempt property that could be seized by the lender is $\max [0, A-E]$. 
Recall that the borrower also incurs an unobserved cost $K$ from defaulting. As a result, he will default only if

$$
\max [0, A-E]+K<D,
$$

where $D$ is the amount due. Throughout this discussion we will assume that the agent acts myopically, in that he considers the costs and benefits of defaulting only in the current period and not any impact that his behavior might have on his future access to credit beyond the default cost $K$; for a more general model which leads to similar conclusions, see Elul [18].

We can now define the notion of a credit score, denoted $\mathcal{S}$. We will let the credit score be the probability that the borrower will not default on a generic loan in the future, given the available information (i.e., given the borrower's repayment history). ${ }^{13}$ In practice, although the default probability clearly depends on $E$ (as shown above), the model used to calculate the credit score does not explicitly make use of geographic variables (see the Fair Isaac "myFICO" web site [19]). This may be because of political sensitivities (on the part of Fair Isaac) or simply because of the practical difficulty of doing so given that approximately $2 \%$ of the U.S. population moves state every year. Notice, however, that there is nothing preventing individual lenders from using this information, although in practice it may be difficult for them to make a precise inference. It is important to point out that we exclude geographic variables such as exemptions from the scoring model solely for the sake of realism; it is not hard to see that allowing exemptions to feature in the scores explicitly would only stregthen our results.

In the following sections we will first calculate the effect of period-0 behavior on future credit scores and then go on to examine the implications of

\footnotetext{
${ }^{13}$ In practice it is the logarithm of the score that is related to the estimated repayment probability.
} 
using these scores for (secured) mortgage lending.

\section{B Unsecured Credit and Credit Scores}

Consider the following very simple extension of our basic model. In this extension we will show first of all that when individual borrowers' default costs are unobservable then credit scores derived from past borrower behavior are useful for predicting their future risk of default on unsecured loans. In addition, we will demonstrate that future default risk is higher - and hence credit scores are lower on average - in states with generous bankruptcy exemptions, even when the exemptions are not explicitly incorporated in the scoring model. In the following section we will apply these scores to secured credit such as mortgages.

Suppose there is a measure 1 of borrowers, each with a fixed default $\operatorname{cost} K$ (which only he observes), and suppose that these costs are uniformly distributed on $[0,1]$. Let half the population be permanently located in a high-exemption state with $E=1$, and the other half live in a low-exemption state with $E=0 .{ }^{14}$ Suppose that in each period an agent receives - and must repay - a new unsecured loan of $D=1 / 2$, and that in each period an individual subsequently receives an iid draw of an asset value $A$, which is uniformly distributed on $[0,1]$.

Consider the situation in period 0 , when borrowers have no credit history. These borrowers default when $\max \left[0, A_{0}-E\right]+K<D$, where $A_{0}$ is this agent's draw of the asset value in period 0 . If $E=0$, a borrower defaults when $A_{0}+K<1 / 2$. The ex-ante probability of period-0 default in this state

\footnotetext{
${ }^{14}$ See Elul and Subramanian [20] for evidence on the impact of bankruptcy laws on migration.
} 
can be determined by integrating these uniform densities:

$$
\int_{0}^{1 / 2} \int_{0}^{1 / 2-K} d A_{0} d K=1 / 8
$$

By contrast, in the state with $E=1$, the asset value is irrelevant (because it is always fully exempt), and a borrower defaults if and only if $K<1 / 2$; as a result, the default probability is $\int_{0}^{1 / 2} d K=1 / 2$.

Averaging over both states, then, the default rate is $1 / 2 \times 1 / 8+1 / 2 \times 1 / 2=$ $5 / 16$. Given that initially we have no information about these borrowers, the ex-ante credit score in period 0 must be the same for each. As discussed above, we do not condition on $E$, in keeping with industry practice. In this case the period- 0 score is $\mathcal{S}_{0}=1-5 / 16=11 / 16$; this is simply the probability that a generic borrower would not default in period 0 . Notice that by not conditioning on the state exemption, we of course overestimate the risk of default for those in the low-exemption state (their conditional probability is actually $1 / 8$ ) and underestimate it for those in the high-exemption state (their risk is 1/2). This is reminiscent of the empirical results of Gross and Souleles [21] and Avery et al. [22], who find that the predictive power of credit scores can be improved if one also accounts for "situational factors," such as regional recessions.

Now consider the situation one period later (period 1). At this point the bureau can update a borrower's score in light of his observed period0 repayment history. Since borrowers' personal default costs are the same across periods, their behavior in the two periods will also be correlated, and thus lenders can use information about a borrower's period-0 repayment history to determine whether or not this borrower will default in the following period. ${ }^{15}$

\footnotetext{
${ }^{15}$ The reader may be concerned that a borrower can only receive a chapter- 7 discharge of debts once every seven years, and so could not default in the future after have defaulted
} 
First, consider those who defaulted in period 0. From above, we can deduce that $\frac{1 / 2 \times 1 / 2}{5 / 16}=4 / 5$ are from the high-exemption state, and $\frac{1 / 2 \times 1 / 8}{5 / 16}=$ $1 / 5$ are from the state with $E=0$. Now, we know that borrowers from the $E=1$ state default (in general) if and only if $K<1 / 2$. Moreover, if this is the case in period 0 , it will continue to be satisfied in period 1 , and so those living in $E=1$ and who defaulted in period 0 will do so in period 1 as well (if the loan is unsecured).

For those living in the low-exemption state, we can use Bayes' Rule to calculate the probability that they will default again in period 1 , conditional on their having defaulted in period 0 . It is:

$$
\operatorname{Prob}\left(\text { Default }_{1} \mid \text { Default }_{0}\right)=\frac{\operatorname{Prob}_{\left(\text {Default }_{1} \wedge \text { Default }_{0}\right)}}{\operatorname{Prob}_{\left(\text {Default }_{0}\right)}}
$$

Now, we know that for these agents the probability of their defaulting in period 0 is $\operatorname{Prob}\left(\right.$ Default $\left._{0}\right)=1 / 8$. In addition, we can also calculate the probability of their defaulting in both periods:

$$
\operatorname{Prob}\left(\text { Default }_{1} \wedge \text { Default }_{0}\right)=\int_{0}^{1 / 2} \int_{0}^{1 / 2-K} \int_{0}^{1 / 2-K} d A_{0} d A_{1} d K=1 / 24 .
$$

So the conditional probability of these agents defaulting in period 1 after having defaulted in period 0 is $\frac{1 / 24}{1 / 8}=1 / 3$.

Finally, we combine these two states together. Since $1 / 5$ of the defaulters were from the low-exemption state and $4 / 5$ from the high-exemption state, the probability of a generic period-0 defaulter defaulting again in period 1 must be $1 / 5 \times 1 / 3+4 / 5 \times 1=13 / 15$. So for those who defaulted in period 0 , their credit score in period 1 will be $\mathcal{S}_{1}=1-13 / 15=2 / 15$.

Similar arguments tell us that those living in the high-exemption state

in the recent past, but this is not a problem once one thinks of default more broadly as a general failure to repay a loan in a timely fashion as agreed; as discussed below, this sort of "informal" default has also been found to be related to exemptions. 
who did not default in period 0 will also not default in period 1 . And another application of Bayes' Rule also tells us that those living in the lowexemption state who did not default in period 0 will also repay in period 1 with $17 / 21$ probability. Since of those who did not default $7 / 11$ are from the low exemption state and 4/11 are from the high-exemption state, ${ }^{16}$ the overall probability of their not defaulting in period 1 having already repaid in period 0 is $\mathcal{S}_{1}=7 / 11 \times 17 / 21+4 / 11 \times 1=29 / 33$.

Although the updated score does not explicitly make use of the exemptions (and, indeed, it still underestimates the risk of default for those in high-exemption states) it is nevertheless the case that those living in highexemption states will have lower scores, on average, simply by virtue of their having a higher risk of defaulting in period 0 . To see this, recall that $1 / 8$ of those in the low-exemption state defaulted in period 0 , so the average period- 1 score in this state will be $1 / 8 \times 2 / 15+7 / 8 \times 29 / 33 \approx 0.786$. By contrast, $1 / 2$ of those living in the $E=1$ state default in period 0 , so their average period- 1 score will be $1 / 2 \times 2 / 15+1 / 2 \times 29 / 33 \approx 0.506$.

\section{Implications for Secured Lending}

We now turn our attention to secured credit. Suppose that the loan (of $D=1 / 2$ ) to be made in period 1 is actually secured by the asset $A-$ e.g., a mortgage on a house. In this case exemptions no longer apply, and default occurs when $A+K<D .{ }^{17}$

We documented above that industry practice involves treating credit scores in a standardized fashion, without controlling for the state exemptions.

\footnotetext{
${ }^{16}$ To see this, recall that $11 / 16$ of the population does not default in period 0 . In addition, we know that half of the population lives in the high-exemption state and that they default with $50 \%$ probability, so $\frac{1 / 2 \times 1 / 2}{11 / 16}=4 / 11$ of those who did not default in period 0 must be from the high-exemption state.

${ }^{17}$ Assuming for simplicity that deficiency judgments are either prohibited or more generally not pursued.
} 
Suppose that - consistent with this practice - lenders apply a standardized rule in which they reject all applications with credit scores below a certain cutoff $\overline{\mathcal{S}}$. In practice this might be a FICO score of 620 . Then an econometrician who estimates the likelihood of credit denial - while controlling for credit scores $\left(\mathcal{S}_{1}\right)$ - would find that while credit scores are significant, exemptions would naturally be irrelevant. We will confirm this in our empirical work below.

We can also consider what happens if the econometrician ignores credit scores altogether and simply regresses the denial probability on the applicant's state exemption; such a procedure reflects the statistical models of LW and BH. Then he would find that exemptions appear to be significant, even though we know that lenders do not make use of exemptions. The reason is that - as we have shown above - credit scores and exemptions are correlated, with those living in the high-exemption state having lower credit scores on average (because of the effect of exemptions on default on unsecured credit). We will verify this empirically below; also note that this is consistent with the results of LW.

The last statement above applies directly to the case of a first-time home buyer, whose credit score is determined solely by his performance on unsecured credit. However, to the extent that applicants' credit files reflect some experience with unsecured credit, exemptions will continue to appear significant when one ignores credit scores. So in practice we should expect our conclusion to apply more generally.

In short, if lenders use a standardized set of rules along the lines we have described to evaluate borrower creditworthiness, we should not expect to find a significant effect of exemptions on the likelihood that a mortgage application is rejected. Furthermore, if one does not control for the credit score in estimating the determinants of an application's being rejected, then it will appear as if exemptions are significant. 
We have focused our analysis on exemptions, but an analogous argument may be made for the effect of a past bankruptcy filing on the approval of a mortgage application. Since a bankruptcy filing reflects not just evidence of a borrower's type but also a response to the legal environment in which the applicant finds himself, to the extent that other legal variables do not affect secured credit, it can also be argued that the credit score may prove to be a somewhat misleading indicator of mortgage default. For example, certain areas may have a "local legal culture" that looks more or less favorably upon bankruptcy (see Sullivan, Warren, and Westbrook [23]), and this will affect

the borrower's credit score, but it should have no effect on the likelihood of mortgage default. Thus, again, when one controls for the score, we should observe that the state bankruptcy rate, say, becomes insignificant or even negative.

This section has discussed the implications of our model when lenders use a standardized policy which treats credit scores uniformly across states. We argued that this is consistent with GSE practice, and likely driven by political sensitivities which would make their favoring one state over another difficult. This is the model which is tested in the following section. In the appendix, however, we treat the case of unconstrained lenders who can freely optimize; as we argue there, the basic thrust of our analysis will remain unchanged.

\section{Data}

We consider a sample of about one million randomly selected applications for conventional mortgages on single-family, owner-occupied properties, drawn from the 1999 HMDA data set. We have data on the loan amount, geographic information to the census-tract level, and some demographic information on the borrower (income, race, and sex). We also add macroeconomic variables at the state, county, and census-tract levels, which we collected from various 
sources (such as bankruptcy rates, house prices, and unemployment rates). We also include legal variables obtained from several sources. The 1998 exemptions are taken from Elias, Renauer, and Leonard [24] (we code an unlimited exemption at $\$ 1 \mathrm{~m}$ following $\mathrm{BH})$, and the state laws governing deficiency judgments were generously provided by Karen Pence [13]. ${ }^{18}$ These variables are summarized in Table 1.

We also have information on borrower creditworthiness from two sources.

First, we have a sample of approximately 150,000 credit bureau files that were randomly drawn from a national credit bureau's files in mid-1999. Each file has a credit risk score associated with it. These scores range from 300 to 850 and are designed to track the common FICO score; they rank order the borrowers (from worst to best) in terms of their likelihood of repaying a generic credit obligation as agreed. ${ }^{19}$ The reader should note that these are the actual credit scores which would be available to mortgage lenders. From this file we compute the average credit score by state.

We have argued that scores and exemptions should be (inversely) correlated, and our model also has this prediction. Although we cannot provide detailed information on the credit scores because of the proprietary nature of the data, we have verified this correlation in two ways. First of all, we can report that the correlation coefficient between scores and exemptions is approximately -0.30 (for both property and homestead exemptions). In addition, we have determined that approximately 10 points of the range (670$720)$ in average state scores is explained by differences in exemptions; that is, moving from the lowest to the highest exemption state would lower scores by 10 points, on average. The remainder of the difference is presumably due

\footnotetext{
${ }^{18}$ There are other state laws that govern the rights of mortgage borrowers and lenders — see Pence [13] and Schill [25].

${ }^{19}$ The ranking is also cardinal in that the log of the likelihood of defaulting on an obligation is approximately linear in the score at any point in time; see, for example, Musto and Souleles [26].
} 
to regional economic differences (see Avery et al. [22] for more on this issue.) In light of previous work, this correlation is not surprising. First, exemptions may affect scores because they make a formal bankruptcy more or less attractive (see Fay, Hurst, and White [8] for empirical verification). In addition, it has also been found that they influence "informal bankruptcy," that is, the failure to repay an obligation even without formally filing for bankruptcy (see Dawsey and Ausubel, [27]): The reasons for this are (1) that even outside of bankruptcy, exemptions can preclude the seizure of property (Berkowitz and Hynes [1]) and (2) that exemptions affect the "outside option" available to creditors and debtors.

Parenthetically, another interesting finding that arises from an analysis of the credit bureau data is that a high homestead exemption lowers the score only for those who actually have a mortgage recorded in their credit bureau file (and thus are presumed to be homeowners); for those who never had a mortgage recorded, the homestead exemption is statistically insignificant (and, in fact, its coefficient is positive!). ${ }^{20}$ That is, not only do exemptions lower scores but the different types of exemption affect scores precisely in the manner expected (i.e., non-homeowners do not care about homestead exemptions).

In addition, to confirm the robustness of our results we supplemented these state-averaged scores with county-level aggregates (for the 4th quarter of 1998). Since our sample of credit bureau files was too small to generate reliable county-level averages for many counties, we obtained these scores from the TrenData database. ${ }^{21}$ The score provided by the TrenData database

\footnotetext{
${ }^{20}$ Some of those who have no mortgage recorded may well still own homes either because they paid off their mortgage in the distant past (although records go back quite a few years) or else the lender failed to report the mortgage. By comparing the bureau files with the PSID asset and liability data, we estimate that approximately $1 / 3$ of those with no mortgage recorded in their bureau files do, in fact, own homes.

${ }^{21}$ TrenData is a product of TransUnion, one of the three major U.S. credit bureaus. The database is based on a series of large random samples of U.S. consumer credit histories
} 
is constructed in the same manner as most industry standard credit scores. The other advantage to this data is that it is available for public purchase, which would allow at least these results to be replicated.

\section{Empirical Results}

\section{A Estimation and Results}

In light of our model and the data we have available, we consider the following specification for the probability of denial of a mortgage loan for applicant $i$ living in state $j$.

$$
\mathcal{P}_{i j}=\beta^{\prime} X_{i j}+\gamma^{\prime} \mathcal{S}_{j}+\delta^{\prime} E_{j}+\epsilon_{i j}
$$

where $X_{i j}$ is a vector of individual and regional variables, $\mathcal{S}_{j}$ is the average credit score in the applicant's state of residence, and $E_{j}$ is a vector consisting of the exemptions (property and homestead) in the state of residence.

Our model predicts that we should have $\gamma<0$ (i.e. a high average credit score makes denial less likely) and that $\delta=0$ (exemptions irrelevant).

We fit a linear probability model of mortgage denial; the results can be found in the first columns of Table $2 .^{22}$ Aside from the credit score, which we have added, most of our variables are the same as those of LW; however, another additional variable is the percentage increase in property values since 1990 (included since it is used by the GSEs). We have reported Huber-White robust standard errors, with clustering at the state level.

drawn quarterly since 1992. From this underlying sample, variables are constructed describing various borrowing and payment attributes of consumers, aggregated to the county level.

${ }^{22}$ We also reran these estimations using a probit model and obtained nearly identical results, which are not reported. 
Our results support our model. First, the coefficient on the credit score is statistically significant. To gauge its economic significance, observe that its value of 0.0038 implies that a 45-point drop in the score from 695 (the national average) to a value of 650 (seen by Fannie Mae as "high-risk") would nearly double the probability of denial from $18 \%$ to $35 \%$, which seems both substantial and also in line with actual credit market practice. Turning to the exemptions, their coefficients are not significant, precisely as our model predicts (and, in fact, the real property exemption's coefficient is negative, albeit insignificant). Other variables generally have the expected signs; to single out just a few: a state prohibition on deficiency judgments makes it harder to obtain a loan, and a high LTI (loan-to-income ratio) is associated with a more successful application (this suggests that LTI is endogenous, as many have argued). Recent increases in housing prices make it harder to obtain a loan (holding the house price constant), which is consistent with a model in which lenders demand some level of LTI or LTV, but a rapidly increasing house price makes it harder to qualify; high house prices are associated with lower denial rates (perhaps because house prices are correlated with income and wealth). Finally, note that the state bankruptcy rate is negative (and statistically significant); this may appear surprising, but recall that bankruptcies also lower scores; so this result may simply reflect mortgage lenders downweighting bankruptcies relative to the weight they have in the credit score. This would be consistent with what we described as "optimizing behavior" in our discussion of the model.

We also consider several alternative specifications. We first drop the loanto-income dummy, since it has been observed that loan amount may well be endogenous. A more complete treatment of this would involve estimating a model of the joint decision of loan size and acceptance; this issue is discussed in greater detail by Ross and Yinger [14]. We also consider the polar opposite and add more variables: an imputed LTV (loan-to-value ratio) based on the 
OFHEO index ${ }^{23}$ and loan amount. The results are qualitatively similar in all of these specifications and are also reported below.

Now consider dropping the credit score variable $\mathcal{S}_{j}$. That is, consider

$$
\mathcal{P}_{i j}=\beta^{\prime} X_{i j}+\delta^{\prime} E_{j}+\epsilon_{i j}
$$

This is the specification considered by both LW and BH.

Examining the results in Table 3, we observe first of all that they are consistent with those of LW, in that high exemptions are associated with a higher likelihood of being denied a mortgage (but they do not support $\mathrm{BH})$. It is important to recall, however, that according to our model, LW's estimates do not reflect the direct use of exemptions by lenders, but rather the correlation between credit scores and exemptions. Also recall that in the empirical estimation of our first specification, including the credit score led the exemptions to be insignificant. The coefficients generally have the same magnitude as LW. For example, moving from the lowest to highest exemption state results in an increase in the denial probability of approximately 3 percentage points (300 basis points); this is comparable to LW's findings.

As we mentioned earlier, to confirm the robustness of our results, we also reran our baseline estimations using county-level average scores as provided by the TransUnion TrenData database. The results, reported in Table 4, are consistent with those obtained using state-level data on scores. Once again, the inclusion of the credit bureau score causes the coefficients on the bankruptcy exemptions to become statistically insignificant (and much smaller in magnitude, although the property exemption no longer changes sign).

Our empirical results confirm that exemptions do not appear to play a significant role in the underwriting decision. They are consistent both with our

\footnotetext{
${ }^{23}$ Since the 1999 HMDA data did not include information on house price.
} 
model and with our description of prevailing industry practice. In addition, we have also demonstrated that some of the previous work may have found significant results because they did not control for borrower creditworthiness. Nevertheless, it is important to note that we are not definitively ruling out either that generous exemptions may slightly increase the cost of foreclosure, nor that they may conversely make it somewhat easier for borrowers to retain their homes in the event of financial distress; indeed, there is some evidence (in work cited above) that both of these effects are occasionally present.

\section{Conclusion}

We have developed a model of mortgage underwriting, in which lenders use credit bureau scores in a standardized fashion, to predict the risk of default of a given applicant. We merge credit scores from a sample of credit bureau files with the HMDA data and estimate our model; this allows us to determine the contribution of credit scores to the risk of being denied a mortgage.

We also show that our model has implications for the debate on the effect of personal bankruptcy exemptions on secured lending. Recent literature (Berkowitz and Hynes [1], Lin and White [2]) has developed conflicting theories - and found conflicting results - seeking to explain how exemptions affect the mortgage market. By contrast, our model implies that exemptions should actually be irrelevant to the credit-granting decision. Moreover, we show that by not controlling for borrower credit quality, the recent literature may find that exemptions appear to be significant. But once one controls for credit scores, then exemptions have no effect on the likelihood that a mortgage application is approved; this is due to the correlation between scores and exemptions. We verify both of these predictions.

By way of conclusion, we venture that this phenomenon may well be more general. Using generic credit scores for mortgage lending allowed bankruptcy 
law to affect the mortgage market. Similarly, the increasing popularity of credit scores in other applications, such as employment and insurance, may allow seemingly irrelevant credit-related factors to impact these decisions as well. This highlights the advantages of market-specific "customized" scores, which use only variables deemed "relevant" to the decision at hand. More generally, it suggests a slightly cautious approach to the current rapid expansion of credit scoring.

\section{References}

[1] J. Berkowitz, R. Hynes, Bankruptcy exemptions and the market for mortgage loans, Journal of Law and Economics 42 (2) (1999) 809830 .

[2] Y. Lin, M. White, Bankruptcy and the market for mortgage and home improvement loans, Journal of Urban Economics 50 (1) (2001) 138162.

[3] K. Temkin, R. Quercia, G. Galster, S. O'Leary, A study of the GSEs' single family underwriting guidelines, Final report, U.S. Department of Housing and Urban Development (April 1999).

[4] J. W. Straka, A shift in the mortgage landscape: The 1990s move to automated credit evaluations, Journal of Housing Research 11 (2) (2000) 207-232.

[5] A. H. Munnell, G. M. Tootell, L. E. Browne, J. McEneaney, Mortgage lending in Boston: Interpreting HMDA data, American Economic Review 86 (1) (1996) 25-53.

[6] I. Barakova, R. W. Bostic, P. S. Calem, S. M. Wachter, Does credit quality matter for homeownership?, Journal of Housing Economics 12 (4) (2003) 318-336. 
[7] A. Pennington-Cross, J. Nichols, Credit history and the FHAconventional choice, Real Estate Economics 28 (2) (2000) 307-336.

[8] S. Fay, E. Hurst, M. J. White, The household bankruptcy decision: Does stigma matter?, American Economic Review 92 (3) (2002) 706-718.

[9] K. Kowalewski, Personal bankruptcy: A literature review, CBO Paper, Congressional Budget Office (September 2000).

[10] R. Gropp, J. K. Scholz, M. J. White, Personal bankruptcy and credit supply and demand, Quarterly Journal of Economics 112 (1) (1997) $217-251$.

[11] B. W. Ambrose, C. A. Capone, Modeling the conditional probability of foreclosure in the context of single-family mortgage default resolutions, Real Estate Economics 26 (3) (1998) 391-429.

[12] T. M. Springer, N. G. Waller, Lender forebearance: Evidence from mortgage delinquency patterns, American Real Estate and Urban Economics Association Journal 21 (1) (1993) 7-46.

[13] K. Pence, Foreclosing on opportunity: State laws and mortgage credit, Finance and Economics Discussion Series 2003-16, Board of Governors of the Federal Reserve System, forthcoming: Review of Economics and Statistics (2003).

[14] S. L. Ross, J. Yinger, The Color of Credit, MIT Press, Cambridge, MA, 2002.

[15] P. Dubey, J. Geanakoplos, M. Shubik, Default and efficiency in a general equilibrium model with incomplete markets, Cowles Foundation Discussion Paper 879R, Yale University (1989).

[16] P. Dubey, J. Geanakoplos, M. Shubik, Default and punishment in general equilibrium, Econometrica 73 (1) (2005) 1-37. 
[17] J. K. Brueckner, Mortgage default with asymmetric information, Journal of Real Estate Finance and Economics 20 (3) (2000) 251-274.

[18] R. Elul, Collateral, credit-history, and the financial decelerator, Working Paper 05-23, Federal Reserve Bank of Philadelphia (2005).

[19] Fair Isaac Corporation, myFICO - What's not in your score, $<$ http://www.myfico.com/myFICO/CreditCentral/ ScoringWorks/ FICOIgnores.asp $>$ (November 2003).

[20] R. Elul, N. Subramanian, Forum shopping and personal bankruptcy, Journal of Financial Services Research 21 (3) (2002) 233-255.

[21] D. B. Gross, N. S. Souleles, An empirical analysis of personal bankruptcy and delinquency, Review of Financial Studies 15 (1) (2002) 319-347.

[22] R. B. Avery, P. S. Calem, G. B. Canner, Consumer credit scoring: Do situational circumstances matter?, Journal of Banking and Finance 28 (4) (2004) 835-856.

[23] T. A. Sullivan, E. Warren, J. L. Westbrook, Consumer bankruptcy in the United States: A study of alleged abuse and of local legal culture, Journal of Consumer Policy 20 (2) (1997) 223-268.

[24] S. Elias, A. Renauer, R. Leonard, How to File for Chapter 7 Bankruptcy, 8th Edition, Nolo Press, Berkeley, CA, 1999.

[25] M. H. Schill, An economic analysis of mortgagor protection laws, Virginia Law Review 77 (1991) 489-538.

[26] D. Musto, N. Souleles, A portfolio view of consumer credit, presentation: Conference on Retail Credit Risk Management and Measurement, Philadelphia Federal Reserve Bank (April 2003).

[27] A. E. Dawsey, L. Ausubel, Informal bankruptcy, unpublished manuscript: Department of Economics, University of Maryland (January 2001). 
Table 1: Summary Statistics

\begin{tabular}{|l|c|} 
Variable & Mean \\
\hline \hline Denied Mortgage & 0.188 \\
\hline Average Credit Score in State & 697 \\
\hline State Homestead Exemption $(\$)$ & 217,177 \\
\hline Personal Prop. Exemption (\$) & 10,152 \\
\hline Deficiency Judgment Prohibited & 0.239 \\
\hline State Bankruptcy Rate (1998) & 0.015 \\
\hline Applicant Income (\$) & 72,026 \\
\hline LTI $\geq 3$ Dummy & 0.138 \\
\hline Loan Amount (\$) & 126,292 \\
\hline Loan-to-Value (LTV) & 0.879 \\
\hline Minority Applicant Dummy Var. & 0.137 \\
\hline Single Applicant Dummy & 0.485 \\
\hline Female Applicant Dummy & 0.197 \\
\hline County Unemp. Rate (\%, 1998) & 3.486 \\
\hline Change in County Income (\$ increase over prev. yr) & 1,836 \\
\hline Median 1990 Tract House Price (\$) & 17,553 \\
\hline MSA House Price Appreciation (TRR, 1990-1998) & 0.262 \\
\hline Minority Population - \% of Tract & 17.6 \\
\hline \hline
\end{tabular}




\section{Appendix - Optimal Lending Policies}

In the body of the paper we explored a model in which lenders were assumed not to make explicit use of exemptions. We justified this on the basis of documented GSE policies, which we suggested were themselves driven either by political considerations or else designed to impose standardization on the mortgage market so as to facilitate securitization. This model had empirical predictions which we verified using our data; it also suggested an explanation of at least some of the previous literature's findings.

In this section we examine what mortgage lenders' optimal policy might be in the context of our model, with particular reference to the role of exemptions. We will see that not only do high exemptions not increase the risk of mortgage default (just as derived above), but in fact they would actually make a borrower more attractive to lenders, ceteris paribus. One intuitive way to see this is to note that an agent from a high-exemption state who did not default in the initial period must be of very good quality, since in this state default on unsecured loans is relatively attractive.

To begin, it is necessary to specify an objective function for the lenders. Suppose, for example, that mortgage lenders would like to maximize lending, subject to the constraint that the average default rate on their mortgage loans does not exceed 15\%. This is fairly reasonable as a rough, qualitative description of GSE policy, although in practice other considerations will of course apply. The maximal default rate of $15 \%$ is adopted purely for expositional convenience and has no empirical significance.

Suppose once again that we are standing in period 1, having observed an applicant's repayment history in period 0 . We first show that lenders will always want to offer mortgages to all those who do not default in period 0 . The difference with the analysis in the body of the paper, however, is that now lenders are free to condition on the exemption in force in the borrower's 
state of residence. Now, for those who did not default in period 0 and live in the $E=1$ state, we know that they will necessarily have $K \geq 1 / 2$, and they will also never default on the mortgage (just as for an unsecured loan); in this case lending to them is a trivial decision. Now, for those living in the $E=0$ state, secured and unsecured loans are equivalent, and so their probability of not defaulting is the same as if the loan were unsecured, i.e., 17/21. Suppose that we lend to these agents as well. It will be useful to recall from above that the set of non-defaulting agents has measure 11/16. Furthermore, since for both of these classes of non-defaulting agents their behavior is independent of whether or not a loan is secured, we can apply our earlier results on unsecured loans and deduce that the overall expected default rate on the mortgages to this pool of agents who did not default in the past will be $4 / 33$. Since this is less than $15 \%$, and since we will show below that even the agents from the low-exemption state who do not default are less risky than any agents who did default (regardless of the latter's state), lending to these agents is both feasible and optimal..

Now by contrast consider those who defaulted in period 0 . We have already seen that these make up 5/16 of the initial pool of borrowers. Of these, $1 / 5$ live in the $E=0$ state and $4 / 5$ in the $E=1$ state. For those who live in the $E=0$ state, unsecured and secured credit are the same, as we have already pointed out, and so, from above, their conditional default rate on the mortgage will be $1 / 3$. By contrast, those who live in the $E=1$ state will be less likely to default on the mortgage than on unsecured credit (in period 1), since exemptions do not apply to the mortgage. In particular, having defaulted in period 0 means that they have a conditional probability of

$$
\frac{\int_{0}^{1 / 2} \int_{0}^{1 / 2-K} d A_{1} d K}{\int_{0}^{1 / 2} d K}=1 / 4
$$

of defaulting on the mortgage in period 1 (by contrast, they would default 
for certain on an unsecured loan, since their assets would always be exempt in this state).

Now consider the following lender policy. Suppose that the lender offers mortgages to all those who did not default in period 0 , as we have argued is indeed optimal above. For those who defaulted in period 0, he randomizes. In particular, for defaulters from the low-exemption state he offers mortgages with probability $\pi_{0}$, and for those who defaulted but are from the highexemption state, he offers mortgages with probability $\pi_{1}$. Then the total measure of agents receiving mortgages in period 1 would be:

$$
11 / 16+\pi_{0} \times(5 / 16 \times 1 / 5)+\pi_{1} \times(5 / 16 \times 4 / 5)=\frac{11+\pi_{0}+4 \pi_{1}}{16}
$$

and the total measure of default on these mortgages would be

$11 / 16 \times 4 / 33+\pi_{0} \times(5 / 16 \times 1 / 5) \times 1 / 3+\pi_{1} \times(5 / 16 \times 4 / 5) \times 1 / 4=\frac{4+\pi_{0}+3 \pi_{1}}{48}$.

The conditional probability of default on the lender's entire portfolio can be obtained by dividing these terms. It is:

$$
\frac{4+\pi_{0}+3 \pi_{1}}{33+3 \pi_{0}+12 \pi_{1}}
$$

Now, if lenders are free to condition their decision in this fashion then it is not hard to see that the optimal policy - i.e. the one which maximizes lending subject to the constraint that the portfolio default rate not exceed $15 \%$ - is to set $\pi_{0}=0$; to keep the default rate no higher than $15 \%$, we would thus need to choose $\pi_{1}=0.79$. This would make the total volume of lending equal to 0.885 . Notice that this optimal policy actually treats those who default in the low-exemption state much more harshly. The intuition is that those who defaulted in the high-exemption state should be treated more leniently in the mortgage market because their prior default can be 
ascribed to its generous exemptions, which do not apply to mortgages (this striking difference in policies suggests that the political economy argument for uniform criteria may well have some merit).

By contrast, suppose lenders are limited to a uniform policy which does not condition on exemptions; recall that we suggested that this is indeed a realistic description of industry practice. In our context this means that they are constrained to set $\pi_{0}=\pi_{1}$. It is now the case that $\pi_{0}=\pi_{1}$ cannot exceed 0.54. At this level, the measure of those who receive loans is 0.857 . Observe that the more uniform policy results in a lower level of lending.

Notice that - at first blush - a rule that ignores exemptions does not appear to be optimal for the lender (nor for society). We have already ventured, however, that lenders - and in particular GSEs - may nevertheless be optimizing in not conditioning their criteria explicitly on exemptions, when one takes into account their political constraints as well as the necessities born of securitization. Of course, this still leaves open the question of whether a uniform policy is indeed socially optimal.

Finally, we can also sketch the implications of this analysis for the empirical data. Notice that, conditional on credit score, high exemptions would actually make an applicant more attractive and therefore less likely to be denied a mortgage. However, if one did not control for scores, then exemptions should appear to be irrelevant to the lending decision. 
Table 2: Denial of Mortgage Applications - Including Score

\begin{tabular}{|c|c|c|c|}
\hline Average Credit Score in State & $\begin{array}{c}-0.0038^{* *} \\
(0.0006) \\
\end{array}$ & $\begin{array}{r}-0.0038^{* *} \\
(0.0006) \\
\end{array}$ & $\begin{array}{r}-0.0038^{* *} \\
(0.0006) \\
\end{array}$ \\
\hline $\begin{array}{l}\text { State Homestead Exemption } \\
(\$ 100,000)\end{array}$ & $\begin{array}{c}0.0011 \\
(0.0011)\end{array}$ & $\begin{array}{c}0.0012 \\
(0.0011)\end{array}$ & $\begin{array}{c}0.0012 \\
(0.0011)\end{array}$ \\
\hline $\begin{array}{l}\text { Personal Prop. Exemption } \\
(\$ 100,000)\end{array}$ & $\begin{array}{l}-0.0639 \\
(0.0734)\end{array}$ & $\begin{array}{l}-0.0704 \\
(0.0712)\end{array}$ & $\begin{array}{l}-0.0633 \\
(0.0733)\end{array}$ \\
\hline $\begin{array}{l}\text { Deficiency Judgment } \\
\text { Prohibited }\end{array}$ & $\begin{array}{l}0.0277^{* *} \\
(0.0103)\end{array}$ & $\begin{array}{l}0.0270^{* *} \\
(0.0103)\end{array}$ & $\begin{array}{l}0.0268^{* *} \\
(0.0103)\end{array}$ \\
\hline State Bankruptcy Rate (1998) & $\begin{array}{c}-2.8693^{* *} \\
(1.477)\end{array}$ & $\begin{array}{c}-2.8492^{* *} \\
(1.443)\end{array}$ & $\begin{array}{c}-2.934^{* *} \\
(1.478)\end{array}$ \\
\hline Applicant Income $(\$ 100,000)$ & $\begin{array}{r}-0.0582^{* *} \\
(0.0155)\end{array}$ & $\begin{array}{r}-0.0341^{* *} \\
(0.0069)\end{array}$ & $\begin{array}{r}-0.0562^{* *} \\
(0.0148)\end{array}$ \\
\hline Income $^{2}\left(\$ 100,000^{2}\right)$ & $\begin{array}{l}0.0008^{* *} \\
(0.0002)\end{array}$ & $\begin{array}{l}0.0005^{* *} \\
(0.0001)\end{array}$ & $\begin{array}{l}0.0008^{* *} \\
(0.0002)\end{array}$ \\
\hline LTI $\geq 3$ Dummy & $\begin{array}{c}-0.0193^{* *} \\
(0.0093)\end{array}$ & $\begin{array}{c}0.0059 \\
(0.0055)\end{array}$ & \\
\hline Loan Amount $(\$ 100,000)$ & & $\begin{array}{c}0.0073 \\
(0.0058)\end{array}$ & \\
\hline Amount $^{2}(\$ 100,000)^{2}$ & & $\begin{array}{l}0.0002^{* *} \\
(0.0001)\end{array}$ & \\
\hline Loan-to-Value (LTV) & & $\begin{array}{c}-0.0418^{* *} \\
(0.0110)\end{array}$ & \\
\hline Minority Applicant Dummy Var. & $\begin{array}{l}0.0708^{* *} \\
(0.0096)\end{array}$ & $\begin{array}{l}0.0680^{* *} \\
(0.0090)\end{array}$ & $\begin{array}{l}0.0707^{* *} \\
(0.0096)\end{array}$ \\
\hline Single Applicant Dummy & $\begin{array}{l}0.0480^{* *} \\
(0.0032)\end{array}$ & $\begin{array}{l}0.0423^{* *} \\
(0.0041)\end{array}$ & $\begin{array}{l}0.0475^{* *} \\
(0.0032)\end{array}$ \\
\hline Female Applicant Dummy & $\begin{array}{c}0.0011 \\
(0.0048)\end{array}$ & $\begin{array}{l}-0.0020 \\
(0.0043)\end{array}$ & $\begin{array}{c}0.0007 \\
(0.0047)\end{array}$ \\
\hline County Unemp. Rate $(\%, 1998)$ & $\begin{array}{c}0.0018 \\
(0.0023)\end{array}$ & $\begin{array}{c}0.0018 \\
(0.0023)\end{array}$ & $\begin{array}{c}0.0018 \\
(0.0023)\end{array}$ \\
\hline $\begin{array}{l}\text { Change in County Income } \\
\text { (increase over prev. yr, } \$ 10,000 \text { ) }\end{array}$ & $\begin{array}{c}-0.1246^{* *} \\
(0.0366)\end{array}$ & $\begin{array}{c}-0.0121^{* *} \\
(0.0037)\end{array}$ & $\begin{array}{c}-0.1253^{* *} \\
(0.0366)\end{array}$ \\
\hline $\begin{array}{l}\text { Median } 1990 \text { Tract House Price } \\
(\$ 100,000)\end{array}$ & $\begin{array}{c}-0.0290^{* *} \\
(0.0093)\end{array}$ & $\begin{array}{c}-0.0004^{* *} \\
(0.0001)\end{array}$ & $\begin{array}{c}-0.0305^{* *} \\
(0.0097)\end{array}$ \\
\hline $\begin{array}{l}\text { MSA House Price Appreciation } \\
\text { (TRR, 1990-1998) }\end{array}$ & $\begin{array}{l}0.0520^{* *} \\
(0.0232)\end{array}$ & $\begin{array}{l}0.0498^{* *} \\
(0.0235)\end{array}$ & $\begin{array}{l}0.0498^{* *} \\
(0.0233)\end{array}$ \\
\hline $\begin{array}{l}\text { Minority Population } \\
\text { Fraction of Tract }\end{array}$ & $\begin{array}{l}0.0010^{* *} \\
(0.0001)\end{array}$ & $\begin{array}{l}0.0011^{* *} \\
(0.0002)\end{array}$ & $\begin{array}{l}0.0010^{* *} \\
(0.0001)\end{array}$ \\
\hline$\overline{\overline{\mathrm{R}^{2}}}$ & 0.0670 & 0.0747 & 0.0667 \\
\hline
\end{tabular}

Number of Observations $=1.15$ million. ${ }^{*}$ denotes significance at the $10 \%$ level, and ${ }^{* *}$ at the $5 \%$ level. Intercept not reported. Huber-White Standard Errors in Parentheses (clustered at state level) 
Table 3: Denial of Mortgage Applications - No Score

\begin{tabular}{|c|c|c|c|}
\hline $\begin{array}{l}\text { State Homestead Exemption } \\
(\$ 100,000)\end{array}$ & $\begin{array}{l}0.0028^{*} \\
(0.0016)\end{array}$ & $\begin{array}{l}0.0028^{*} \\
(0.0017)\end{array}$ & $\begin{array}{l}0.0028^{*} \\
(0.0016)\end{array}$ \\
\hline $\begin{array}{l}\text { Personal Prop. Exemption } \\
(\$ 100,000)\end{array}$ & $\begin{array}{l}0.1502^{* *} \\
(0.0756)\end{array}$ & $\begin{array}{l}0.141^{* *} \\
(0.0752)\end{array}$ & $\begin{array}{l}0.1524^{* *} \\
(0.0756)\end{array}$ \\
\hline $\begin{array}{l}\text { Deficiency Judgment } \\
\text { Prohibited }\end{array}$ & $\begin{array}{l}-0.0089 \\
(0.0114)\end{array}$ & $\begin{array}{l}-0.0091 \\
(0.0114)\end{array}$ & $\begin{array}{l}-0.0102 \\
(0.0117)\end{array}$ \\
\hline State Bankruptcy Rate (1998) & $\begin{array}{c}0.7351 \\
(1.6466)\end{array}$ & $\begin{array}{c}0.7079 \\
(1.6218)\end{array}$ & $\begin{array}{c}0.6864 \\
(1.6577)\end{array}$ \\
\hline Applicant Income $(\$ 10,000)$ & $\begin{array}{c}-0.0578^{* *} \\
(0.0153)\end{array}$ & $\begin{array}{c}-0.0334^{* *} \\
(0.0066)\end{array}$ & $\begin{array}{c}-0.0556^{* *} \\
(0.0146)\end{array}$ \\
\hline Income $^{2}\left(\$ 10,000^{2}\right)$ & $\begin{array}{l}0.0008^{* *} \\
(0.0002)\end{array}$ & $\begin{array}{l}0.0005^{* *} \\
(0.0001) \\
\end{array}$ & $\begin{array}{l}0.0008^{* *} \\
(0.0002)\end{array}$ \\
\hline$\overline{L T I} \geq 3$ Dummy & $\begin{array}{c}-0.0221^{* *} \\
(0.0095)\end{array}$ & $\begin{array}{c}0.0034 \\
(0.0058) \\
\end{array}$ & \\
\hline Loan Amount $(\$ 100,000)$ & & $\begin{array}{l}-0.0075 \\
(0.0058)\end{array}$ & \\
\hline $\operatorname{Amount}^{2}\left(\$ 100,000^{2}\right)$ & & $\begin{array}{l}0.0002^{* *} \\
(0.0001)\end{array}$ & \\
\hline Loan-to-Value (LTV) & & $\begin{array}{c}-0.0421^{* *} \\
(0.0112) \\
\end{array}$ & \\
\hline Minority Applicant Dummy Var. & $\begin{array}{l}0.0738^{* *} \\
(0.0104)\end{array}$ & $\begin{array}{l}0.0710^{* *} \\
(0.0098)\end{array}$ & $\begin{array}{l}0.0737^{* *} \\
(0.0105)\end{array}$ \\
\hline Single Applicant Dummy & $\begin{array}{l}0.0495^{* *} \\
(0.0032)\end{array}$ & $\begin{array}{l}0.0438^{* *} \\
(0.0438)\end{array}$ & $\begin{array}{l}0.0490^{* *} \\
(0.0032)\end{array}$ \\
\hline Female Applicant Dummy & $\begin{array}{c}0.0021 \\
(0.0049)\end{array}$ & $\begin{array}{c}0.0011 \\
(0.0044)\end{array}$ & $\begin{array}{c}0.0016 \\
(0.0048)\end{array}$ \\
\hline County Unemp. Rate $(\%, 1998)$ & $\begin{array}{c}0.0013 \\
(0.0024)\end{array}$ & $\begin{array}{c}0.0013 \\
(0.0024)\end{array}$ & $\begin{array}{c}0.0013 \\
(0.0024)\end{array}$ \\
\hline $\begin{array}{l}\text { Change in Median County Income } \\
\text { (increase over prev. yr, } \$ 10,000 \text { ) }\end{array}$ & $\begin{array}{c}-0.1204^{* *} \\
(0.0045)\end{array}$ & $\begin{array}{c}-0.0117^{* *} \\
(0.0045)\end{array}$ & $\begin{array}{c}-0.0121^{* *} \\
(0.0045)\end{array}$ \\
\hline $\begin{array}{l}\text { Median } 1990 \text { Tract House Price } \\
(\$ 100,000)\end{array}$ & $\begin{array}{c}-0.0346^{* *} \\
(0.0114)\end{array}$ & $\begin{array}{c}-0.0427 \\
(0.0130)\end{array}$ & $\begin{array}{c}-0.0363^{* *} \\
(0.0118)\end{array}$ \\
\hline $\begin{array}{l}\text { MSA House Price Appreciation } \\
\text { (TRR, 1990-1998) }\end{array}$ & $\begin{array}{l}0.0810^{* *} \\
(0.0278)\end{array}$ & $\begin{array}{l}0.0785^{* *} \\
(0.0287)\end{array}$ & $\begin{array}{l}0.0788^{* *} \\
(0.0283)\end{array}$ \\
\hline $\begin{array}{l}\text { Minority Population } \\
\text { Fraction of Tract }\end{array}$ & $\begin{array}{l}0.0012^{* *} \\
(0.0002)\end{array}$ & $\begin{array}{l}0.0013^{* *} \\
(0.0002)\end{array}$ & $\begin{array}{l}0.0012^{* *} \\
(0.0002)\end{array}$ \\
\hline$\overline{\mathrm{R}^{2}}$ & 0.0607 & 0.0686 & 0.0604 \\
\hline
\end{tabular}

Number of Observations $=1.15$ million. ${ }^{*}$ denotes significance at the $10 \%$ level, and ${ }^{* *}$ at the $5 \%$ level. Intercept not reported. Huber-White Standard Errors in Parentheses (clustered at state level) 
Table 4: Denial of Mortgage Applications - County-Level Scores

\begin{tabular}{|l|c|c|}
\hline & No Score & County Score \\
\hline \hline Average Credit Score in County & & $-0.0014^{* *}$ \\
& & $(0.0003)$ \\
\hline State Homestead Exemption & $0.0028^{*}$ & 0.0014 \\
$(\$ 100,000)$ & $(0.0016)$ & $(0.0014)$ \\
\hline Personal Prop. Exemption & $0.1502^{* *}$ & 0.0365 \\
$(\$ 100,000)$ & $(0.0756)$ & $(0.0735)$ \\
\hline Deficiency Judgment & -0.0089 & -0.0021 \\
Prohibited & $(0.0114)$ & $(0.0098)$ \\
\hline State Bankruptcy Rate $(1998)$ & 0.7351 & -1.2680 \\
& $(1.6466)$ & $(1.6306)$ \\
\hline Applicant Income (\$10,000) & $-0.0578^{* *}$ & $-0.0582^{* *}$ \\
& $(0.0153)$ & $(0.0154)$ \\
\hline Income ${ }^{2}$ (\$10,000 $\left.{ }^{2}\right)$ & $0.0008^{* *}$ & $0.0008^{* *}$ \\
& $(0.0002)$ & $(0.0002)$ \\
\hline LTI $\geq 3$ Dummy & $-0.0221^{* *}$ & $-0.0196^{* *}$ \\
& $(0.0095)$ & $(0.0098)$ \\
\hline Minority Applicant Dummy Var. & $0.0738^{* *}$ & $0.0698^{* *}$ \\
& $(0.0104)$ & $(0.0098)$ \\
\hline Single Applicant Dummy & $0.0495^{* *}$ & $0.0472^{* *}$ \\
& $(0.0032)$ & $(0.0031)$ \\
\hline Female Applicant Dummy & 0.0021 & 0.0013 \\
& $(0.0049)$ & $(0.0049)$ \\
\hline County Unemp. Rate (\%, 1998) & 0.0013 & -0.2691 \\
& $(0.0024)$ & $(0.2799)$ \\
\hline Change in Median County Income & $-0.1204^{* *}$ & $-0.0814^{* *}$ \\
(increase over prev. yr, \$10,000) & $(0.0045)$ & $(0.0341)$ \\
\hline Median 1990 Tract House Price & $-0.0346^{* *}$ & $-0.0280^{* *}$ \\
$(\$ 100,000)$ & $(0.0114)$ & $(0.0109)$ \\
\hline MSA House Price Appreciation & $0.0810^{* *}$ & $0.0795^{* *}$ \\
(TRR, 1990-1998) $)$ & $(0.0278)$ & $(0.0259)$ \\
\hline Minority Population & $0.0012^{* *}$ & $0.0010^{* *}$ \\
Fraction of Tract & $(0.0002)$ & $(0.0001)$ \\
\hline \hline $\mathrm{R}^{2}$ & 0.0624 & 0.0646 \\
\hline
\end{tabular}

Number of Observations $=1.15$ million. ${ }^{*}$ denotes significance at the $10 \%$ level, and ${ }^{* *}$ at the $5 \%$ level. Intercept not reported. Huber-White Standard Errors in Parentheses (clustered at state level) 